Jurnal Progres Ekonomi Pembangunan (JPEP)

Volume 4, Nomor 2, Tahun 2019

Page: 91-100

http://ojs.uho.ac.id/index.php/JPEP

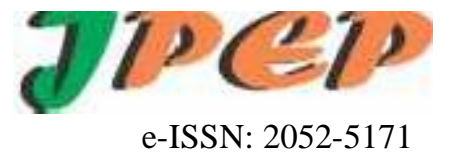

\title{
DETERMINAN INVESTASI \\ PENANAMAN MODAL DALAM NEGERI (PMDN) DI INDONESIA
}

\author{
${ }^{1}$ Frisnawati Yunus \\ Program Pascasarjana Universitas Halu Oleo Kendari \\ e-mail: frisna.yunus@gmail.com \\ ${ }^{2}$ Rostin \\ Universitas Halu Oleo, Kendari \\ e-mail: $\underline{\text { rostin@uho.ac.id }}$ \\ ${ }^{3}$ Wali Aya Rumbia \\ Universitas Halu Oleo, Kendari \\ e-mail: walirumbia@uho.ac.id
}

\begin{abstract}
Abstrak
The purpose of this study is to analyze how the effect of Product Domestic Bruto, Goverment Expenditure, Interest Rate, Inflation and Excange Rate on Domestic Investment in Indonesia. The type of reseacrh is quantitative. The type of data is secondary. The data used is time series from 1988-2017. The analysis method was the Error Correction Modhel (ECM).

The result of the study to show that: 1). Product Domestic Bruto is positive not significantly effect; 2). Goverment ekspenditure is positive significantly effect; 3) Interes Rate is possitive significantly effect; 4). Inflation is negative significantly effect; 4). Exchange Rate is negative significantly effect.

Keywords: Product Domestic Bruto, Goverment Expenditure, Interest Rate, Inflation, Exchange Rate and Domestic Investment.

\section{Pendahuluan}

Perekonomian Indonesia merosot saat krisis moneter pada Tahun 1997-1998, krisis multidimensi yang berdampak pada kondisi Indonesia secara umum. Pertumbuhan ekonomi yang buruk, Suku Bunga yang tinggi berdampak pada meningkatnya harga-harga secara continue dalam jangka waktu yang cukup lama atau yang disebut Inflasi, bahkan berimbas pula pada Nilai Tukar Rupiah yang terdepresiasi sangat tajam. Kondisi tersebut membuat Indonesia memerlukan dana baru dalam hal pembangunan ekonomi, karena secara perhitungan ekonomi saat itu, Indonesia tidak mempunyai tabungan yang cukup untuk meredam gejolak ekonomi yang terjadi. Salah satu cara yang ditempuh adalah dengan adanya bantuan lembaga finansial internasional dan mengundang sejumlah Investor untuk memulai menanamkan modalnya di Indonesia.

Investasi merupakan komponen agregat demand yang paling tidak stabil dibanding dengan komponen agregat demand lainnya. Investasi mempengaruhi fluktuasi ekonomi. Tanjung (2007:2) dalam Tesisnya menyebutkan, secara umum tujuan pokok dari adanya kegiatan Investasi adalah untuk meningkatkan produksi, penyempurnaan struktur industri, penciptaan lapangan pekerjaan, pemerataan pendapatan, pemanfaatan sumber daya alam dan manusia, mendorong ekspor dan memelihara lingkungan. Sehingga lingkaran perangkap kemiskinan yang banyak terjadi di negara berkembang dapat berkurang melalui Investasi.
\end{abstract}


Jurnal Progres Ekonomi Pembangunan (JPEP)

Volume 4, Nomor 2, Tahun 2019

Page: $91-100$

http://ojs.uho.ac.id/index.php/JPEP

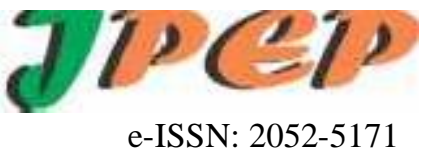

Beberapa penelitian tentang diperlukannya Investasi sebagai pemulihan ekonomi antaralain penelitian yang dilakukan oleh Setyawan dan Fatchurrohman (2004) dalam Paper yang disampaikan pada Seminar Nasional Akademik Tahun 2004 mengungkapkan bahwa pemulihan ekonomi sebenarnya akan lebih ditentukan oleh pemulihan Investasi. Dengan mengutip Kuncoro (2000), Setyawan menjelaskan bahwa dalam teori Neo-Klasik selalu diajarkan bahwa untuk membangun kinerja perekonomian suatu negara maka dibutuhkan akumulasi kapital.

Investasi PMDN di Indonesia dari Tahun 1988-2017 mengalami fluktuasi dari Tahun ke Tahun. Investasi terendah terjadi pada Tahun 1988 yakni Rp15,680.9 (Milliar) dan tertinggi terjadi pada Tahun 2017 yakni Rp262,350.5 (Milliar). Meskipun adanya fluktuasi tersebut namun terjadi peningkatan drastis sejak Tahun 2010 yakni Rp60.626.300 (Milliar) hingga Tahun 2017 yakni Rp262.350.500. Fluktuasi Investasi ini tentu dipengaruhi oleh berbagai faktor.

Menurut Samuelson dan Nordhaus (1992: 136) bahwa PDB merupakan salahsatu komponen yang mempengaruhi Investasi. Pertumbuhan PDB dari Tahun 1988-2017 mengalami peningkatan. Peningkatan tersebut tidak mempunyai pengaruh yang menonjol terhadap Investasi. Karena Produk Domestik Bruto pada Tahun 2012 turun Rp4.027.753 (Milliar) tetapi Investasi pada Tahun tersebut justru meningkat Rp92.182.000 (Milliar). Begitu pula peningkatan PDB yang terjadi pada Tahun 2008 tidak mempengaruhi peningkatan Investasi dimana Investasi pada Tahun tersebut justru menurun Rp20.363.400 (Milliar). Hal ini bertolak belakang dengan kajian empiris bahwa PDB berpengaruh positif signifikan terhadap Investasi (Sakr, 1993; Haque, Husain dan Montiel, 1991; Naqvi, 2002);

Pemerintah telah menempuh berbagai cara untuk meningkatkan Investasi, salahsatunya melalui intervensi Pengeluaran Pemerintah. Pengeluaran Pemerintah merupakan instrumen pengukur dimana Pemerintah menentukan seberapa besar peran sektor Pemerintah dan sektor swasta. Pada tahap awal perkembangan ekonomi diperlukan Pengeluaran Pemerintah yang besar untuk Investasi Pemerintah utamanya dalam menyediakan infrastruktur seperti jalan, fasilitas keamanan, kesehatan dan pendidikan. (Wahyuningtyas, 2010: 38)

Salahsatu topik yang menimbulkan perbedaan pendapat di kalangan ahli ekonomi baik secara teoritis maupun empiris adalah hubungan Pengeluaran Pemerintah dengan Investasi. Ekonom klasik berpendapat bahwa peningkatan Pengeluaran Pemerintah menyebabkan meningkatnya Suku Bunga yang mendorong Investasi menurun. Penurunan ini terjadi ketika kebijakan fiskal ekspansioner dan aktivitas Pemerintah dibiayai melalui pinjaman yang mengarah pada peningkatan Suku Bunga pasar dan peningkatan biaya modal terhadap sektor swasta. Namun di sisi lain, ekonom Keynesian berpendapat bahwa peningkatan Pengeluaran Pemerintah menyebabkan infastruktur, kesehatan, pendidikan lebih baik yang dapat menambah daya tarik Investasi karena pengeluaran ini dapat mengurangi biaya produksi perusahaan dan konsekwensinya terhadap Investasi. (Ahmad \& Miller, 1999; Ahmad \& Qayyum, 2008; Mohammad \& Husein, Mohammad, 2009)

Tingkat Suku Bunga yang kondusif juga sering dijadikan Pemerintah sebagai instrumen kebijakan untuk menarik minat Investor menanamkan modalnya. Tingkat Suku Bunga menjadi salahsatu faktor yang signifikan bagi Investor untuk melihat laba atau rugi dari proyek-proyek Investasi yang akan dilakukan. (Jamli Ahmad dan Firmansyah, 1998: 54)

Secara teoritis Suku Bunga berhubungan negatif terhadap Investasi. Suku Bunga yang tinggi akan meningkatkan real cost of capital yang akan menghambat Investasi (Nurdeen, 2009). Namun hal yang berbeda diungkapkan oleh McKinnon (1973) dan Shaw 
Jurnal Progres Ekonomi Pembangunan (JPEP)

Volume 4, Nomor 2, Tahun 2019

Page: $91-100$

http://ojs.uho.ac.id/index.php/JPEP

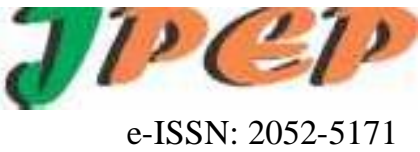

(1973) dalam Khan dan Khan (2007) bahwa kemungkinan ada hubungan positif antara Investasi dengan tingkat Suku Bunga, karena peningkatan Suku Bunga akan meningkatkan tabungan sehingga volume kredit dalam negeri akan meningkat dan menghasilkan equilibrium Investasi yang lebih tinggi. Sejalan dengan temuan Ang (2009) bahwa Suku Bunga berhubungan positif terhadap Investasi.

Tinggi rendahnya Suku Bunga merupakan salahsatu dampak Inflasi. Berdasarkan data BPS Indonesia dari Tahun 1988-2017 bahwa Inflasi tertinggi terjadi pada Tahun 1998 yakni $77.60 \%$, karena krisis ekonomi. Meskipun demikian, tingginya Inflasi tersebut tidak menurunkan Investasi secara drastis. Bahkan pada Tahun 1999 Inflasi menurun 2\% tetapi tidak mempengaruhi peningkatan Investasi, karena Investasi pada Tahun tersebut justru menurun sebesar Rp53.550.000 (Milliar). Hal ini bertolak belakang dengan temuan Greenee dan Villamueva (1991), Everhart (2001), Agenor (2002), Kok dan Ersoy (2009) bahwa Inflasi berpengaruh negatif terhadap Investasi.

Selain itu, salah satu faktor penentu dominan yang mempengaruhi Investasi adalah Nilai Tukar. (Dua dan Grag, 2013). Nilai Tukar mencerminkan kondisi perekonomian suatu negara. Semakin stabil Nilai Tukar mata uang suatu Negara terhadap mata uang Negara lain, semakin menunjukan kekuatan fundamental perekonomian Negara tersebut. Nilai Tukar Rupiah atas Dolllar Amerika Serikat mengalami peningkatan. Peningkatan tersebut bepengaruh pada peningkatan Investasi yang lebih menonjol dari Tahun 2010-2017. Hal ini bertolak belakang dengan temuan Al Hasymi (2010:2) bahwa Nilai Tukar berpengaruh negatif terhadap Investasi.

Oleh karena berdasarkan temuan-temuan yang masih ambigu tersebut di atas maka penulis tertarik untuk menganalisis dan membuktikannya melalui penelitian ini yang berjudul Determinan Investasi Penanaman Modal Dalam Negeri di Indonesia.

\section{Tinjauan Pustaka}

Menurut Paul A. Samuelson dan William D. Nordhaus (1998), Investasi dalah pengeluaran yang dilakukan oleh para penanam modal yang menyangkut penggunaan sumber-sumber seperti peralatan, gedung, peralatan produksi dan mesin-mesin baru lainnya atau persediaan yang diharapkan akan memberikan keuntungan dari Investasi tersebut. Kekuatan ekonomi utama yang menentukan Investasi adalah hasil biaya Investasi yang ditentukan oleh kebijakan tingkat bunga dan pajak, serta harapan mengenai masa depan.

Pengertian Investasi Penanaman Modal Dalam Negeri (PMDN) yang terkandung dalam Undang-Undang Nomor 6 Tahun 1968 tentang Penanaman Modal Dalam Negeri (PMDN) mencakup kriteria sebagaiberikut:

a. Bagian dari kekayaan masyarakat Indonesia;

b. Dimiliki oleh Negara atau pun swasta Nasional dan swasta Asing yang berdomisili di Indonesia;

c. Guna menjalankan suatu usaha; dan

d. Modal tersebut tidak termasuk dalam pengertian pasal 2 Undang-Undang No. 1 Tahun 1967 tesebut di atas (Pasal 1 ayat 1).

Investasi PMDN merupakan bagian dari penggunaan kekayaan yang dapat dilakukan secara langsung oleh pemilik sendiri atau secara tidak langsung, antaralain melalui pembelian obligasi, saham deposito dan tabungan yang jangka waktunya minimal 1 Tahun.

Dalam analisis ekonomi, ada 2 pendekatan yang dapat digunakan dalam menentukan prospek suatu kegiatan produksi yakni sebagaiberikut: 
Jurnal Progres Ekonomi Pembangunan (JPEP)

Volume 4, Nomor 2, Tahun 2019

Page: $91-100$

http://ojs.uho.ac.id/index.php/JPEP

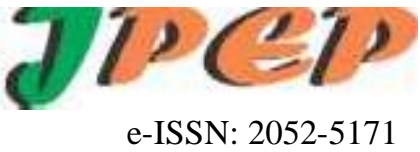

1) Menentukan nilai sekarang dari pendapatan netto yang diperoleh sepanjang umur ekonomi proyek tersebut.

Dengan pendekatan ini, sesuatu proyek dikatakan menguntungkan apabila nilai sekarang dari pendapatan neto proyek tersebut adalah melebihi biaya yang dibelanjakan untuk mewujudkan proyek tersebut. Dengan demikian persamaan yang menyatakan syarat bagi suatu proyek menguntungkan adalah $\mathrm{PV}_{\mathrm{A}}>\mathrm{C}_{\mathrm{A}}$

Dimana:

$\mathrm{PV}_{\mathrm{A}}$ : Nilai sekarang pendapatan neto proyek $\mathrm{A}$

$\mathrm{C}_{\mathrm{A}}$ : Biaya yang dibelanjakan untuk mewujudkan proyek A.

Yang dimaksudkan dengan pendapatan neto di sini adalah hasil penjualan yang akan diperoleh setelah dikurangi dengan biaya-biaya operasi yang dikeluarkan pada Tahun sepanjang umur ekonomi proyek tersebut.

2) Menentukan tingkat pengembalian modal (rate of return) suatu proyek.

Yang dimaksud dengan tingkat pengembalian modal adalah pendapatan bersih suatu proyek yang dinyatakan presentase dari modal yang ditanamkan dalam pengembangan suatu proyek. Dengan demikian syarat yang menunjukan bahwa suatu proyek itu menguntungkan dapat digambarkan bawa $\mathrm{R}>\mathrm{r}$, dimana:

$\mathrm{R}$ : Presentase pengembalian modal

$\mathrm{r}$ : Suku Bunga

Teori Investasi Klasik berpendapat bahwa terdapat fleksibilitas tingkat Bunga yang akan menjamin terwujudnya keadaan tabungan selalu sama dengan Investasi (I=S) sehingga keseimbangan antara tabungan dan Investasi selalu tercapai. Dengan kata lain, tingkat Bunga merupakan hasil interaksi antara tabungan (S) dan Investasi (I). (Sukirno, 2016)

Keynes berpendapat bahwa Investasi bertumpu pada harapan keuntungan atau Marginal Efficiency Of Capital (MEC) yang merupakan Determinan kunci sekaligus ukuran tentang tingkat keuntungan yang diharapkan (expected profitability) dari suatu Investasi. Marginal Efficiency Of Capital (MEC) merupakan suatu tingkat diskonto yang menyamakan the present value penerimaan Investasi di masa yang akan datang dengan current supply price atau current replacement cost Investasi tersebut. Marginal Efficiency of Capital (MEC) adalah tingkat pengembalian dari suatu proyek Investasi. Angka $M E C$ ini adalah angka yang menyamakan harga Investasi dengan nilai sekarang (present value) dari semua penerimaan yang diharapkan dari nilai sisa (residu) Investasi tersebut. (Suparmono, 2004)

Menurut Jogerson bahwa Investor yang rasional dan profitmaximizer akan memperhitungkan present value imbalan keputusan Investasinya dan akan menyamakan marginal benefit dengan marginal cost dari Investasi yang direncanakan. (Jorgenson, 1967)

1. Produk Domestik Bruto

Terdapat keterkaitan yang erat antara Produk Domestik Bruto dalam Pendapatan Nasional dan Investasi. Hubungan keduanya menjadi suatu sorotan para ekonom, baik dari kalangan Klasik maupun Neo Klasik. Teori Pendapatan Nasional Keynesian yang menggunakan pendekatan pengeluaran agregatif, dimana besarnya Pendapatan Nasional suatu negara diukur dari komponen-komponen expenditure para pelaku ekonominya lewat anggaran-anggarannya yaitu; sektor rumah tangga $(\mathrm{C})$, perilaku usaha dan dunia usaha tercermin lewat komponen Investasi (I) yang ditanam, Pemerintah melalui anggaran belanjanya $(\mathrm{G})$ dan sektor perdagangan internasional yang tercermin lewat nilai ekspor/impor netto. Teori diatas selanjutnya menurunkan pertimbangan parsial pada faktor-faktor yang menjadi pertimbangan dalam melakukan Investasi. Seperti halnya dalam konsumsi yang dilakukan oleh sektor rumah tangga, Investasi oleh para 
Jurnal Progres Ekonomi Pembangunan (JPEP)

Volume 4, Nomor 2, Tahun 2019

Page: $91-100$

http://ojs.uho.ac.id/index.php/JPEP

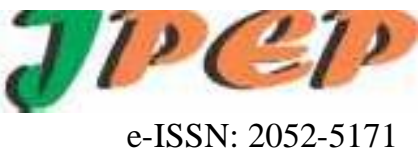

pengusaha ditentukan oleh beberapa faktor. Salah satu diantara faktor-faktor penting yang dipertimbangkan adalah besarnya nilai Pendapatan Nasional yang dicapai (Sukirno, 2006)

2. Pengeluaran Pemerintah

Pengeluaran Pemerintah merupakan instrumen pengukur dimana Pemerintah menentukan seberapa besar peran sektor Pemerintah dan sektor swasta. Pada tahap awal perkembangan ekonomi diperlukan Pengeluaran Pemerintah yang besar untuk Investasi Pemerintah utamanya dalam menyediakan infrastruktur seperti jalan, fasilitas keamanan, kesehatan dan pendidikan. Pengeluaran Pemerintah dapat digunakan sebagai penentu pokok jumlah pengeluaran agregat serta penentu pertumbuhan Produk Nasional Bruto rill dalam jangka pendek. Pengeluaran Pemerintah mencerminkan kebijakan Pemerintah. Apabila Pemerintah telah menetapkan suatu kebijakan untuk membeli barang dan jasa maka Pengeluaran Pemerintah mencerminkan biaya yang harus dikeluarkan oleh Pemerintah untuk melaksanakan kegiatan tersebut. (Mangkoesubroto, 1996: 196)

3. Suku Bunga

Keynes berpendapat bahwa tingkat Bunga merupakan suatu fenomena moneter. Artinya, tingkat Bunga ditentukan oleh penawaran dan permintaan uang (ditentukan dalam pasar uang). Uang akan mempengaruhi kegiatan ekonomi (GNP), sepanjang uang ini mempengaruhi tingkat Bunga. Perubahan tingkat Bunga selanjutnya akan mempengaruhi keinginan untuk mengadakan Investasi dengan demikian akan mempengaruhi GNP. Dalam pandangan Keynes terhadap besarnya Investasi, dia beranggapan bahwa tingkat Bunga bukan merupakan satu - satunya komponen utama dalam menentukan besarnya Investasi. Besarnya Investasi juga ditentukan oleh faktor lain seperti keadaan ekonomi pada masa kini, ramalan perkembangan di masa depan, dan tingkat penggunaan dan perkembangan teknologi. Jadi meskipun tingkat Bunga tinggi, namun apabila keadaan perekonomian sekarang baik untuk dilakukan Investasi dan prospek ke depannya sangat baik, maka kegiatan Investasi tetap akan dilakukan.

4. Inflasi

Menurut Keynes kuantitas uang tidak berpengaruh terhadap tingkat permintaan total, karena perekonomian dapat mengalami Inflasi walaupun tingkat kuantitas uang konstan. Jika uang beredar bertambah maka harga akan naik yang menyebabkan bertambahnya permintaan uang untuk transaksi, sehingga akan menaikkan Suku Bunga. Hal ini akan mencegah pertambahan permintaan untuk Investasi dan akan melunakkan tekanan Inflasi. Menurut Keynes, Inflasi permintaan yang benar - benar penting adalah yang ditimbulkan oleh Pengeluran Pemerintah, terutama yang berkaitan dengan peperangan, program Investasi yang besar - besaran dalam capital sosial.

Teori Moneterisme berpendapat bahwa, Inflasi disebabkan oleh Kebijakan Moneter dan Fiskal yang ekspansif, sehingga jumlah uang beredar di masyarakat sangat berlebihan menyebabkan terjadinya kelebihan permintaan barang dan jasa di sektor riil. Inflasi dapat diturunkan dengan cara menekan kelebihan permintaan melalui Kebijakan Moneter dan Fiskal yang bersifat kontraktif, atau melalui kontrol terhadap peningkatan upah serta penghapusan terhadap subsidi atas nilai tukar valuta asing.

5. Nilai Tukar

Nilai Tukar (Exchange Rate) atau yang biasa disebut dengan Kurs Mata Uang adalah catatan harga pasar dari Mata Uang Asing (foreign currency) dalam harga Mata Uang Domestik (domestic currency). Nilai Tukar merepresentasikan tingkat harga pertukaran dari satu mata uang ke mata uang lainnya dan digunakan dalam berbagai transaksi, 
Jurnal Progres Ekonomi Pembangunan (JPEP)

Volume 4, Nomor 2, Tahun 2019

Page: 91-100

http://ojs.uho.ac.id/index.php/JPEP

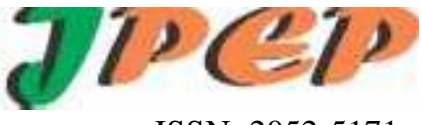

e-ISSN: 2052-5171

antaralain transaksi perdagangan internasional, tourisme, Investasi internasional, maupun aliran uang jangka pendek antar negara yang melewati batas-batas gegrafis maupun batas-batas hukum. (Adiwarman, 2010:13)

Secara teoritis dampak perubahan tingkat Nilai Tukat terhadap Investasi bersifat unsertenty atau tidak pasti. Pengaruh tingkat Nilai Tukar yang berubah pada Investasi dapat langsung melalui 2 saluran yakni sisi permintaan dan sisi penawaran domestik. Dalam jangka pendek, penurunan Nilai Tukar akan mengurangi Investasi melalui pengaruh negatifnya pada expenditure reducing effect. Karena penurunan Nilai Tukar ini akan menyebabkan nilai rill aset masyarakat yang disebabkan kenaikan tingkat hargaharga secara umum dan selanjutnya akan menurunkan permintaan domestik. Hal ini menurunkan pengeluaran/ alokasi modal Investasi. (Muhammad Al Hasymi, 2010:2)

\section{Metodologi Penelitian}

Penelitian ini menggunakan pendekatan kuantitatif. Jenis data yaitu data sekunder yang bersumber dari website BPS Nasional, Bank Indonesia dan Kementrian Keuangan. Data yang digunakan adalah time series dari Tahun 1988-2017. Teknik analisis data dalam penelitian ini adalah Error Correction Modhel (ECM) yang diolah dengan menggunakan Eviews10.

\section{Hasil Analisis \\ Uji Asumsi Klasik}

a. Uji Normalitas

Tabel 1.1

Hasil Uji Normalitas

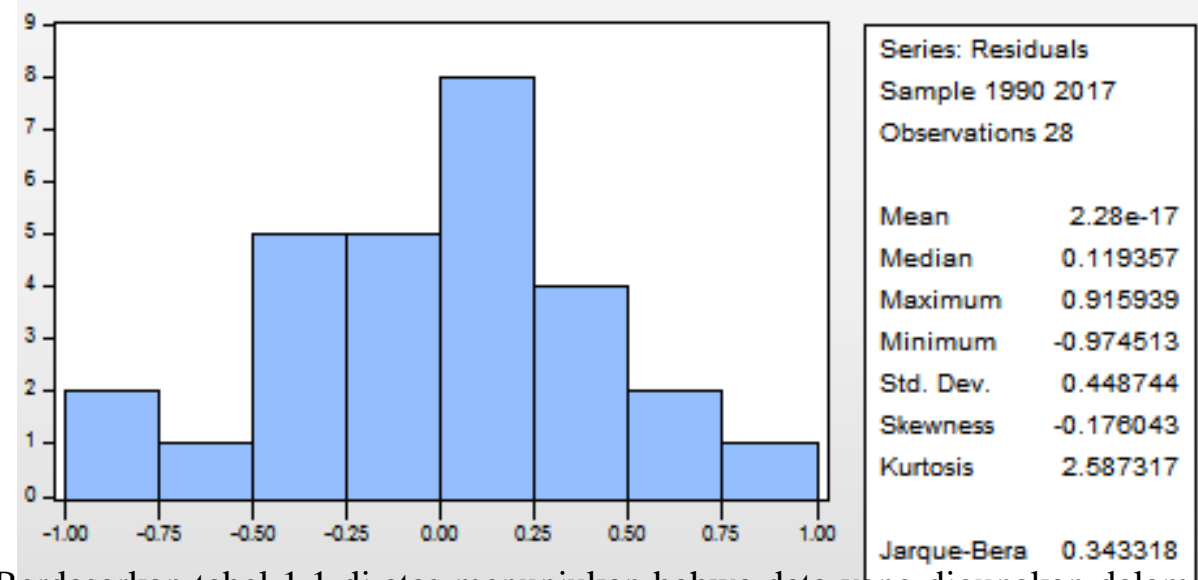

Berdasarkan tabel 1.1 di atas menunjukan bahwa data yang digngakan penelitian ini berdistribusi normal. Hal ini dilihat dari nilai probabilitasnya $>0,05$ yakni 0,842266 .

b. Uji Multikolinearitas

Tabel 1.2

Hasil Uji Multikolinearitas

\begin{tabular}{cccc}
\hline \hline Variable & $\begin{array}{c}\text { Coefficient } \\
\text { Variance }\end{array}$ & $\begin{array}{c}\text { Uncentered } \\
\text { VIF }\end{array}$ & $\begin{array}{c}\text { Centered } \\
\text { VIF }\end{array}$ \\
\hline \hline C & 0.032093 & 3.305487 & NA \\
DPDB & 0.257542 & 1.796030 & 1.141620 \\
DG & 0.355863 & 2.175854 & 1.265465 \\
DIR & 0.442060 & 5.188582 & 5.111004 \\
DIR(-1) & 0.153564 & 1.806211 & 1.777992 \\
DINFLASI & 0.053626 & 5.576749 & 5.574967 \\
DKURS & 0.548597 & 1.960178 & 1.669275 \\
E(-1) & 0.056772 & 1.246879 & 1.245755 \\
\hline \hline
\end{tabular}


Jurnal Progres Ekonomi Pembangunan (JPEP)

Volume 4, Nomor 2, Tahun 2019

Page: $91-100$

http://ojs.uho.ac.id/index.php/JPEP

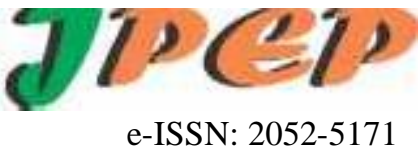

Berdasarkan tabel 1.2 di atas menunjukan bahwa dalam model yang digunakan penelitian ini tidak terjadi multikolinearitas. Hal ini dilihat dari nilai Centered VIF masing-masing variabel > 10 .

c. Heterokedastisitas

Tabel 1.3

Hasil Uji Heterokedastisitas

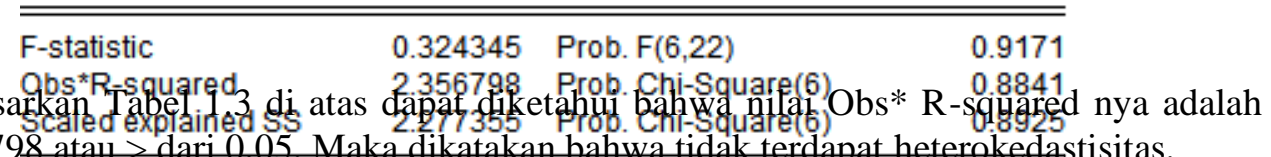

2,356798 atau > dari 0,05. Maka dikatakan bahwa tidak terdapat heterokedastisitas.

d. Autokorelasi

Tabel 1.4

Hasil Uji Autokorelasi

\begin{tabular}{llll}
\hline \hline F-statistic & 0.008646 & Prob. F(2,18) & 0.9914 \\
Obs*R-squared & 0.026872 & Prob. Chi-Square(2) & 0.9867 \\
\hline \hline
\end{tabular}

Berdasarkan tabel 1.4 di atas dapat diketahui bahwa nilai probabilitas Obs* R-Squared > 0,05 yakni 0,9867 maka dapat dikatakan bahwa model dalam penelitian ini tidak terjadi autokorelasi.

\section{Uji Akar Unit}

Tabel 1.5

Hasil Uji Akar Unit

\begin{tabular}{|c|c|c|c|c|c|}
\hline \multirow{2}{*}{ Variabel } & \multirow{2}{*}{ t-Stastistik } & \multicolumn{3}{|c|}{ Nilai Kritis } & \multirow{2}{*}{ Probabiltas } \\
\cline { 3 - 5 } & & $1 \%$ level & $5 \%$ level & $10 \%$ level & \\
\hline PDB & -1.042470 & -3.689194 & -2.971852 & -2.625121 & 0.7236 \\
\hline G & -1.051937 & -3.689194 & -2.971853 & -2.625121 & 0.7201 \\
\hline IR & -1.490557 & -3.679322 & -2.967767 & -2.622989 & 0.5241 \\
\hline INFLASI & -5.679161 & -3.679322 & -2.967767 & -2.622989 & 0.0001 \\
\hline KURS & -1.490557 & -3.679322 & -2.967767 & -2.622989 & 0.5241 \\
\hline Y & -2.416978 & -3.679322 & -2.967767 & -2.622989 & 0.1460 \\
\hline
\end{tabular}

Berdasarkan Tabel 1.5 di atas dapat diketahui bahwa terdapat beberapa variabel yang ada tidak stasioner pada tingkat level, diantaranya PDB nilai probabilitas 0,7236; Pengeluaran Pemerintah $(\mathrm{G})$ dengan nilai probabilitas 0,7291; Suku Bunga (Ir) dengan nilai probabilitas 0,0953; Nilai Tukar (Kurs) dengan nilai probabilitas 0,8484; dan Investasi PMDN (Y) dengan nilai probabilitas 0,1460. Variabel tersebut tidak stasioner karena nilai probabilitasnya $>5 \%$. Olehkarena itu, maka perlu dilakukan uji derajat integrasi untuk melihat seberapa besar tingkat derajat variabel non stasioner tersebut.

\section{Uji Derajat Integrasi}

Tabel 1.6

Hasil Uji Derajat Integrasi

\begin{tabular}{|c|c|c|c|c|c|}
\hline \multirow{2}{*}{ Variabel } & \multirow{2}{*}{ t-Statistik } & \multicolumn{3}{|c|}{ Nilai Kritis } & \multirow{2}{*}{ Probabiltas } \\
\cline { 3 - 5 } & & $1 \%$ level & $5 \%$ level & $10 \%$ level & \\
\hline PDB & -8.428272 & -3.689194 & -2.971853 & -2.625121 & 0.0000 \\
\hline G & -5.752990 & -3.689194 & -2.971853 & -2.625121 & 0.0001 \\
\hline
\end{tabular}


Jurnal Progres Ekonomi Pembangunan (JPEP)

Volume 4, Nomor 2, Tahun 2019

Page: $91-100$

http://ojs.uho.ac.id/index.php/JPEP

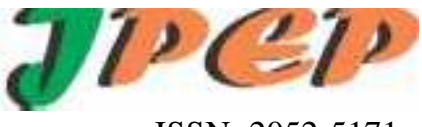

e-ISSN: 2052-5171

\begin{tabular}{|c|c|c|c|c|c|}
\hline IR & -6.114801 & -3.699871 & -2.976263 & -2.627420 & 0.0000 \\
\hline INFLASI & -5.481084 & -3.679322 & -2.967767 & -2.622989 & 0.0049 \\
\hline KURS & -3.982991 & -3.689194 & -2.971853 & -2.625121 & 0.0010 \\
\hline Y & -6.979343 & -3.689194 & -2.971853 & -2.625121 & 0.0000 \\
\hline
\end{tabular}

Berdasarkan hasil uji unit root pada Tabel 1.9 di atas dapat diketahui bahwa semua variabel sudah stasioner pada tingkat first difference dengan tingkat kepercayaan $1 \%, 5 \%$ dan $10 \%$. Dengan demikian dapat dijelaskan bahwa seluruh variabel dalam penelitian ini telah stasioner pada derajat integrasi yang sama.

\section{Penentuan Lag Optimum}

Tabel 1.7

Hasil Uji Vector Autoregression Estimate

\begin{tabular}{ccccccc}
\hline \hline Lag & LogL & LR & FPE & AIC & SC & HQ \\
\hline \hline 0 & -55.19281 & NA & $5.07 \mathrm{e}-05$ & 4.299487 & 4.537380 & 4.372213 \\
1 & 52.60994 & $169.4043^{\star}$ & $1.42 \mathrm{e}-07$ & -1.614996 & $-0.187634^{\star}$ & $-1.178637^{\star}$ \\
2 & 80.97330 & 34.44123 & $1.35 \mathrm{e}-07^{\star}$ & $-1.855236^{\star}$ & 0.761594 & -1.055245 \\
\hline \hline
\end{tabular}

Berdasarkan tabel 1.7 di atas menunjukan bahwa nilai yang paling kecil pada kriteria $A I C$ dan $S C$ terdapat pada lag 1 . Sehingga dengan demikian lag optimum yang digunakan dalam penelitian ini adalah 1 .

\section{Uji Kointegrasi}

Tabel 1.8

Hasil Uji Kointegrasi

\begin{tabular}{|l|c|c|c|}
\hline \multicolumn{1}{|c|}{ Variabel } & Koefisien & t-Statistik & Probabilitas \\
\hline PDB & 0.621384 & 1.070045 & 0.2967 \\
\hline PDB(-1) & 0.514244 & 0.863103 & 0.3978 \\
\hline G & 1.557312 & 2.126059 & 0.0455 \\
\hline G(-1) & -1.283647 & -1.907367 & 0.0702 \\
\hline Suku Bunga & 1.546602 & 0.729819 & 0.0462 \\
\hline Inflasi & -0.456673 & -1.705532 & 0.1028 \\
\hline Kurs & -1.627169 & -2.333665 & 0.0296 \\
\hline C & 2.611053 & 0.822163 & 0.4202 \\
\hline R-Squared F- & \multicolumn{3}{|l}{0.589871} \\
\hline $\begin{array}{l}\text { Probabilitas } \\
\text { Statistik }\end{array}$ & & 0.004224 & \\
\hline
\end{tabular}

Berdasarkan tabel 1.8 di atas diperoleh persamaan berikut:

$\mathrm{Y}_{\mathrm{t}}=\quad 2,611053+0,621384 * \mathrm{PDB}_{\mathrm{t}-0}+0,5214244 * \mathrm{PDB}_{\mathrm{t}-1}+1,557312 * \mathrm{G}_{\mathrm{t}-0}-1,283647 * \mathrm{G}_{\mathrm{t}-}$ ${ }_{1}+1,546602 * \mathrm{IR}_{\mathrm{t}-0}-0.456673 * \mathrm{INFLASI}_{\mathrm{t}-0}-1,627169 * \mathrm{KURS}_{\mathrm{t}-0}$

Interpretasinya adalah sebagaiberikut:

1. Produk Domestik Bruto (PDB) mempunyai nilai koefisien positif yakni 0.621384. Hal ini berarti bahwa apabila terjadi peningkatan $1 \%$ pada PDB akan meningkatkan Investasi PMDN 0,62\%. Demikian sebaliknya apabila terjadi penurunan PDB \% akan menurunkan Investasi PMDN 0,62\%;

2. Pengeluaran Pemerintah bernilai positif yakni 1,625494. Hal ini berarti bahwa apabila terjadi peningkatan $1 \%$ pada Pengeluaran Pemerintah akan meningkatkan Investasi 
Jurnal Progres Ekonomi Pembangunan (JPEP)

Volume 4, Nomor 2, Tahun 2019

Page: 91-100

http://ojs.uho.ac.id/index.php/JPEP

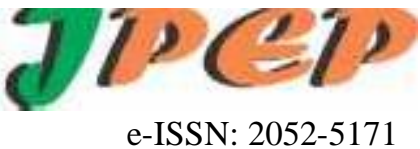

PMDN 1,62\%. Demikian sebaliknya apabila terjadi penurunan $1 \%$ pada Pengeluaran Pemerintah akan menurunkan 1,62\% Investasi PMDN;

3. Koefisien Suku Bunga (IR) bernilai positif yakni 1,395573. Hal ini berarti bahwa apabila terjadi peningkatan 1\% pada Suku Bunga akan meningkatkan 1,39\% Investasi PMDN. Demikian sebaliknya apabila terjadi penurunan $1 \%$ Suku Bunga akan menurunkan $1,39 \%$ Investasi PMDN;

4. Koefisien Inflasi bernilai negatif yakni $-1,252936$. Hal ini berarti bahwa apabila terjadi peningkatan $1 \%$ pada Inflasi akan menurunkan 1,25\% Investasi PMDN. Demikian sebaliknya apabila terjadi penurunan Inflasi 1\% akan meningkatkan 1,25\% Investasi PMDN;

5. Koefisien Nilai Tukar (Kurs) bernilai negatif yakni $-0,644245$. Hal ini berarti bahwa apabila terjadi peningkatan $1 \%$ pada Nilai Tukar akan menurunkan $0,64 \%$ Investasi PMDN. Demikian sebaliknya apabila terjadi penurunan $1 \%$ Nilai Tukar akan meningkatkan 0,64\% Investasi PMDN.

\section{Uji Error Correction Modhel (ECM)}

\section{Tabel 1.9}

Hasil Uji $E C M$

\begin{tabular}{|l|c|c|c|}
\hline \multicolumn{1}{|c|}{ Variabel } & Koefisien & t-Statistik & Probabilitas \\
\hline DPDB & 0.108869 & 0.214527 & 0.8323 \\
\hline DG & 1.450068 & 2.437086 & 0.0246 \\
\hline DIR & 1.397557 & 2.101980 & 0.0484 \\
\hline DIR(-1) & 0.112469 & 0.287004 & 0.7771 \\
\hline DINFLASI & -0.340644 & -1.470001 & 0.1569 \\
\hline DKURS & -1.415789 & -1.911489 & 0.0704 \\
\hline C & -0.007452 & -0.041600 & 0.9672 \\
\hline E(-1) & -0.605847 & -2.542698 & 0.0194 \\
\hline R-Squared & \multicolumn{3}{|c|}{0.517920} \\
\hline $\begin{array}{l}\text { Probabilitas F- } \\
\text { Statistik }\end{array}$ & \multicolumn{3}{|l}{} \\
\hline
\end{tabular}

Berdasarkan tabel 5.16 hasil uji $E C M$ di atas diperoleh persamaan:

$\mathrm{Y}_{\mathrm{t}}=-0,007452+0,108869 * \mathrm{DPDB}_{\mathrm{t}-0}+1,450068 * \mathrm{DG}_{\mathrm{t}-0}+1,397557 * \mathrm{DIR}_{\mathrm{t}-0}+$

$1.112469 * \mathrm{DIR}_{\mathrm{t}-1}-0,340644 * \mathrm{DINFLASI}_{\mathrm{t}-0}-1,415789 * \mathrm{DKURS}_{\mathrm{t}-0}+\mathrm{E}(-1)$

Interpretasinya adalah sebagaiberikut:

1. Produk Domestik Bruto (PDB) mempunyai nilai koefisien positif yakni 0,108869. Hal ini menunjukan bahwa apabila terjadi kenaikan PDB sebesar $1 \%$ maka akan menyebabkan kenaikan pula pada Investasi PMDN sebesar 0.10\%. Demikian sebaliknya apabila terjadi penurunan PDB 1\% maka akan menurunkan Investasi PMDN 0,10\%;

2. Pengeluaran Pemerintah $(G)$ mempunyai nilai koefisien positif yakni 1.450068. Hal ini menunjukan bahwa apabila terjadi kenaikan $\mathrm{G}$ sebesar $1 \%$ maka akan menyebabkan kenaikan pada Investasi PMDN sebesar 1,5\%. Demikian sebaliknya apabila terjadi penurunan Pengeluraan Pemerintah maka akan menurunkan Investasi PMDN 1,5\%;

3. Suku Bunga mempunyai nilai koefisien positif yakni 1,397557. Hal ini menunjukan bahwa apabila terjadi kenaikan Suku Bunga sebesar 1\% maka akan menyebabkan kenaikan pada Investasi PMDN sebesar 1,39\%; Demikian sebaliknya apabila terjadi penurunan Suku Bunga 1\% maka akan menurunkan Investasi PMDN 1,39\%; 
Jurnal Progres Ekonomi Pembangunan (JPEP)

Volume 4, Nomor 2, Tahun 2019

Page: $91-100$

http://ojs.uho.ac.id/index.php/JPEP

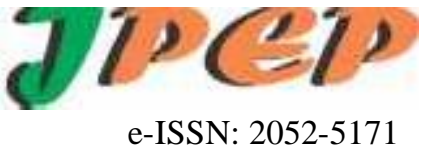

4. Inflasi mempunyai nilai koefisien negatif yakni -0,340644. Hal ini menunjukan bahwa apabila terjadi kenaikan Inflasi sebesar 1\% maka akan menyebabkan penurunan Investasi PMDN sebesar 0,34\%. Demikian sebaliknya apabila terjadi penurunan Inflasi maka akan meningkatkan Investasi PMDN 0,34\%;

5. Nilai Tukar mempunyai nilai koefisien yang negatif yakni -1,41. Hal ini menunjukan bahwa apabila terjadi kenaikan Nilai Tukar sebesar 1\% maka akan menyebabkan penurunan Investasi PMDN sebesar 1,41\%. Demikian sebaliknya apabila terjadi penurunan Nilai Tukar 1\% maka akan meningkatkan Investasi PMDN 1,41\%.

\section{Pembahasan}

\section{a. Pengaruh PDB terhadap Investasi}

Produk Domestik Bruto (PDB) berpengaruh positif tidak signifikan. Hubungan yang positif ini menunjukan bahwa PDB berbanding lurus dengan Investasi PMDN di Indonesia. Yang artinya apabila PDB meningkat maka akan menurunkan Investasi. Demikian pula sebaliknya apabila PDB menurun maka kan menurunkan Investasi.

Pengaruh yang tidak signifikan ini karena dalam jangka panjang maupun jangka pendek PDB ditentukan oleh beberapa komponen keseimbangan dalam perekonomian. Dimana fluktuasi PDB tidak langsung berimbas pada Investasi PMDN, melainkan terlebihdahulu berimbas pada konsumen rumah tangga. Dimana dari sudut perekonomian negara konsumen yang berhemat atau kurang melakukan konsumsi dapat mengurangi tingkat kegiatan ekonomi. Sedangkan dalam perekonomian, pengeluaran agregat termasuk konsumsi rumah tangga adalah penentu utama keseimbangan pendapatan nasional dalam hal ini PDB.

Salahsatu dampak konsumen yang berhemat ini akan meningkatkan tabungan yang dapat berimbas pada pengurangan dalam konsumsi dan pengeluaran atau pengeluaran agregat

yang akan menurunkan PDB. Fenomena ini dinamakan paradoks berhemat atau paradox of thrift.

Hal ini relevan dengan teori Menurut Jhingan (2010: 340) bahwa peningkatan PDB berdampak pada kenaikan laju pembentukan modal. Hubungan antara PDB dengan Investasi PMDN bahwa tingkat pendapatan nasional yang tinggi akan memperbesar pendapatan masyarakat dan selanjutnya pendapatan masyarakat tersebut akan memperbesar permintaan terhadap barang-barang dan jasa-jasa, maka keuntungan perusahaan yang akan bertambah tinggi ini akan mendorong dilakukannya lebih banyak Investasi.

\section{v Pengaruh Pengeluaran Pemerintah terhadap Investasi}

Pengeluaran Pemerintah berpengaruh positif terhadap Investasi PMDN di Indonesia. Nilai positif ini menunjukan bahwa hubungan antara Pengeluran Pemerintah berbanding lurus dengan Investasi, yang artinya apabila Pengeluaran Pemerintah meningkat maka akan menyebabkan peningkatan pada Investasi. Begitu juga sebaliknya, apabila Pengeluaran Pemerintah menurun maka akan menurunkan Investasi.

Dalam jangka panjang maupun jangka pendek Pengeluaran Pemerintah berpengaruh signifikan terhadap Investasi PMDN. Hal ini karena Pengeluaran Pemerintah dilakukan untuk membiayai kegiatan-kegiatan pembangunan. Dimana pengeluaran-pengeluaran yang dilakukan Pemerintah tersebut akan meningkatkan pengeluaran agregat dan mempertinggi tingkat kegiatan ekonomi Negara. Kondisi ini tentu merespon daya tarik Investasi.

Hal ini sejalan dengan temuan Adrian Sutawijaya (2013) bahwa ada hubungan positif antara Pengeluaran Pemerintah dengan Investasi. Dengan demikian bahwa hipotesis dalam penelitian ini adalah $\mathrm{H}_{0}$ ditolak atau hipotesis diterima. 